\title{
PROCESSING TECHNOLOGY AND THE INDUSTRIAL APPLICATION OF WHEY
}

\section{TECHNOLOGIA PRZETWÓRSTWA I WYKORZYSTANIE SERWATKI W PRZEMYŚLE}

Department of Dairy Technology and Food Storage, West Pomeranian University of Technology, Szczecin, Poland

\begin{abstract}
Streszczenie. Serwatka to produkt uboczny przemysłu mleczarskiego powstający podczas produkcji serów oraz kazeiny. Pomimo niskiej zawartości suchej masy serwatka stanowi cenny pod względem właściwości funkcjonalnych i odżywczych surowiec o wysokim potencjale aplikacyjnym. W przeszłości była ona postrzegana jako uciążliwy odpad, jednakże obecnie, z uwagi na wzrastającą wielkość produkcji oraz coraz lepsze poznanie korzystnych właściwości, stale opracowywane są nowe kierunki jej wykorzystania. Celem pracy było przedstawienie metod stosowanych w przetwórstwie serwatki oraz scharakteryzowanie preparatów otrzymywanych na jej bazie. Ponadto w pracy przedstawiono aktualne kierunki wykorzystania serwatki, przede wszystkim w produkcji żywności, a także w innych gałęziach przemysłu.
\end{abstract}

Key words: whey, whey processing, whey powder, whey protein concentrates, whey protein isolates.

Słowa kluczowe: serwatka, przetwórstwo serwatki, serwatka w proszku, koncentraty białek serwatkowych, izolaty białek serwatkowych.

\section{INTRODUCTION}

Whey is a residue that remains after the formation of curds during cheese or casein production. It is a yellow-greenish liquid with salty taste. Cheesemaking industry provides large quantities of whey, which constitutes to $90 \%$ of milk used in the production (Pescuma et al. 2010). Approximately $33 \%$ of the world milk production is used in cheese manufacture. Global whey production in 2010 was established at 165 million tones and about $68 \%$ of this amount was produced in Europe (Darade and Ghodake 2012; Pereira et al. 2015). Additionally, trends show that the world whey production increases approximately by $2 \%$ per year (Dajnowiec and Zander 2013).

During cheese production, approximately $50 \%$ of milk dry matter goes to whey and it contains about $6.3-7 \%$ of milk solids. Main ingredient is lactose, which accounts for $4.5-5 \%$ of whey. Other solids are whey proteins $(0.6-0.8 \%)$, fat $(0.4-0.5 \%)$ and mineral salts (app. $0.5 \%$ ), mainly calcium and phosphorus. Whey is a good source of vitamins from group B.

Corresponding author - Adres do korespondencji: Katarzyna Skryplonek, Department of Dairy Technology and Food Storage, West Pomeranian University of Technology, Szczecin, Papieża Pawła VI 3, 71-459 Szczecin, Poland, e-mail: katarzyna.skryplonek@zut.edu.pl 
The presence of significant amounts of riboflavin (vit. $B_{2}$ ) is responsible for the greenish color of whey. Moreover acid whey contains considerable amounts of lactic acid (app. 0.6\%) (Gonzáles Siso 1996; Mclntosh et al. 1998; Smithers 2008). It is well known that whey components have easy digestibility, high nutritional value and positive impact on the body functions (Żelazna and Popielarska 2003; Kłobukowski and Kozikowski 2008). Thus whey and whey formulations are considered as appropriate ingredients for promoting nutritive value and organoleptic properties of number of food products.

\section{PROCESSING TECHNOLOGY AND RECEIVING OF WHEY PREPARATIONS}

The constant increase of whey production and recognition of whey as a source of unique physiological and functional attributes, contributed to the development of the whey processing technology. The processing of whey is fast-growing industry which involves the usage of such techniques as membrane separation, chromatography or electrodialysis. Currently, the whey usage is increasingly common in many branches of the food industry. In addition, it finds many applications in the pharmaceutical, cosmetical, biotechnological and feed industry (Pescuma et al. 2008; Smithers 2008). It is estimated, that global market of whey and whey formulations has a value of app. $6.3 \times 10^{9}$ Euros (Pereira et al. 2015).

Whey, as a liquid with high level of nutrients, is very perishable material. In order to inactivate the microflora responsible for the spoilage, the processing is usually preceded by a short-term pasteurization and cooling (Bednarski 2001). The heat treatment causes the whey protein denaturation, and therefore the process can be replaced by sterilization by UV radiation (Mahmoud and Ghaly 2004). Subsequently, standardized whey is usually subjected to processes of concentration and fractionation of ingredients. The industrial production of whey formulations normally involves a final drying step, carried out in spray dryer.

The aim of membrane filtration is to divide whey ingredients on the basis of particles size. Water and particles with size smaller than the size of membrane pores, pass through the membrane forming a permeate. While the particles of larger dimension are retained by the membrane and form a retentate (concentrate). Due to the size of membrane pores, several membrane techniques with different applications can be distinguished. Reverse osmosis (RO) is a technique with the smallest dimension of separated particles ranged from $10^{-4}$ to $10^{-3} \mu \mathrm{m}$. RO enables the concentration of all whey ingredients and the membrane permeates only water. Another technique of membrane filtration is nanofiltration (NF) which retains in retentate particles larger than $10^{-3}-10^{-2} \mu \mathrm{m}$. In this process, salts, ions and part of water pass through the membrane. Additionally, in case of acid whey, the removal of lactic acid occurs. As a result, there is obtained demineralised and concentrated whey without salty and sour aftertaste. Obtaining of the neutral taste of whey is significant in case of its further utilization in the food industry. The sensory properties of whey formulations are transferred to the product, therefore NF technique increases the usefulness of whey as an ingredient of food products. Low content of mineral salts causes that NF whey concentrate may be use in infant nutrition. The NF permeate which consists of water, ions and minerals is used as a source of minerals for example in animal feeding or may be utilized for cleaning purposes. The retentate of RO and NF separation, after spray drying gives respectively whey powder 
and demineralized whey powder. In order to improve the solubility, whey powders may undergo the process of agglomeration in fluidized bed (Zander and Zander 2007, Prazeres et al. 2012; Tavares et al. 2012).

Ultrafiltration (UF) allows the retention of particles with size larger than $10^{-2}-10^{-1} \mu \mathrm{m}$. In this process, lactose and minerals pass through the membrane while whey proteins as a particles with bigger dimension, retain in retentate. It leads to obtain the permeate, which is rich in lactose and minerals and the retentate, rich in proteins. In order to increase the whey protein concentration, UF retentate may be diluted with water and again directed to UF process. This double or triple ultrafiltration is referred as diafiltration. Retentate after UF or diafiltration, after spray drying process, gives whey protein concentrates (WPC). Concentrate after single UF process contains app. $35 \%$ of proteins. Diafiltration leads to increasing protein content to the value of app. $65 \%$ and $80 \%$ respectively for double and triple filtration. Concentrates with more than $85-90 \%$ of whey proteins are referred as whey protein isolates (WPI). UF permetate is used as lactose source. In order to facilitate the lactose receiving, UF permeate is subjected to reverse osmosis process, which leads to increase the lactose concentration (Leman and Dolgan 2001; de la Fuente et al. 2002; Chojnowski and Dec 2008).

The membrane filtration with the largest pores in membrane is microfiltration (MF). In this process water and all whey ingredients pass through the membrane and form permeate, while suspended particles with size $10^{-1}-10^{1} \mu \mathrm{m}$ like casein curd particles, fat globules and microorganisms goes to retentate (Kroll and Budzyński 2001; Tavares et al. 2012).

Due to physical nature and no need of thermal treatment, techniques of membrane filtration do not cause thermal denaturation of whey proteins nor vulnerable vitamins degradation. Obtained products have high nutritional and functional attributes and find a number of applications, above all in the food industry (Bednarski 2001).

The most difficult procedure in whey processing is to isolate the individual whey proteins, however advances in fractionation and purification technologies allowed to develop the methods for preparation of formulations comprising a single protein. These technologies are based on such processes as ion exchange chromatography or selective precipitation. Received formulations of main whey proteins $\beta$-lactoglobulin and $\alpha$-lactalbumin, are used in infant nutrition, cosmetic and pharmaceutical products. More expensive formulations of minor whey proteins including bioactive proteins like lactoferrin, lactoperoxidase and immunoglobulins are used in pharmaceutical industry. Due to low concentration of bioactive proteins in whey $(20-40 \mathrm{mg} / \mathrm{l})$, the production of formulations of these proteins requires the processing of large quantities of whey and the use of a number of step processes. It results in high production cost and high prices of these formulations (Bednarski 2001; Smithers 2008).

Another formulation received from whey are whey protein hydrolysates (WPH) obtained by enzymatic hydrolysis. The partial hydrolysis of whey proteins reduces allergenicity, increases thermal stability and modifies its functional characteristics while maintaining a high nutritional value. WPH are used as a component of hypoallergenic ingredient of infant formulations and in athletes nutrition (Foegeding et al. 2002; Leman 2006). Whey proteins may be subjected to another enzymatic modification which is cross-linking process by means of transglutaminase or tyrosinase enzymes (Leman 2006; Clare and Daubert 2010). Apart from enzymatic modifications, whey protein concentrates can undergo physical process of 
particulation involving heating and shearing in order to obtain aggregates with diameter ranging from 1 to $10 \mu \mathrm{m}$. These aggregates reffered as microparticulated whey proteins (MWP) are used as a fat replacers (Szymański et al. 2010; Torres et al. 2011).

\section{THE USE OF WHEY AND WHEY FORMULATIONS IN THE FOOD INDUSTRY}

Industrial utilization of fluid whey is limited mainly due to the low dry matter content and the variability of chemical composition. Fluid whey may substitute water or milk in bread and other bakery and confectionery products, in which it enhance crumb structure, crust browning and flavor (Kosikowski 1979; Kakan et al. 2015). Marriott et al. (1998) reported that fluid whey can replace $30 \%$ of water in cured ham formulation. Incorporation of whey resulted in similar appearance, flavour and stability in comparison to control product. Yetim et al. $(2001,2006)$ pointed out, that fluid whey may be incorporated into comminuted meat products. Addition of whey to frankfurter-type sausage formulation, due to emulsifier and water binding capacity of whey proteins, significantly improved emulsion stability without adverse effects on sensory properties. Even $100 \%$ substitution of ice with fluid whey did not affected textural and color characteristics of the sausages.

In dairy industry whey is traditionally used to whey cheese manufacturing. They are prepared in process involving application of heat and often the addition of organic acid (e.g. acetic, citric) and/or mineral salt (e.g. calcium), to the whey. Whey may be also enriched with milk, which facilitates formation of a firmer curd. To improve the production yield, the whey can be pre-concentrated in UF process. A typical example of the whey cheese is the Italian Ricotta. This prepared from Mozzarella whey cheese is white in color, and has a delicate and grainy texture. Because of short shelf-life, Ricotta is intended to be consumed soon after manufacturing. Other short shelf-life whey cheese is Greek Manouri. Scandinavian products like Gjetost and Mysost which are prepared from concentrated whey, have longer shelf-life (Smithers 2008; Philippopoulos and Papadakis 2001). Moreover fluid whey is sometimes added to fresh milk as a factor decreasing the $\mathrm{pH}$ and accelerating coagulation process. The best example of this procedure is the production of popular Italian cheese Parmigiano-Reggiano, where the whey derived from the previous day of the cheese production constitutes a source of thermophilic lactic acid bacteria (de Roest and Menghi 2000). The high nutritional value of whey encouraged its use in a variety of beverages. Until now, a wide range of whey drinks have been developed and some of them are commercially produced. There are many types of whey drinks like unfermented and fermented beverages, drinks with fruits or vegetable juices, milk-type drinks, refreshing soft drinks and alcoholic beverages (Chavan et al. 2015b). One of the most popular commercial whey-based beverage is produced in Switzerland Rivella. This available in several European countries, thirst quenching drink is usually made of deproteinated whey and water with addition of sugar and flavours. Whey can also be used as a substitute of wort in beer production. It may be either combined with the wort in varying ratio or may be fermented alone. Well-known example of this kind of beer is manufactured from Stilton cheese whey English "The Blue Brew" (Jeličić et al. 2008; Chavan et al. 2015b). 
In the food industry, much greater importance than the fluid whey, have whey-derived formulations such as whey powder, demineralised whey powder, whey protein concentrates and isolates and modified whey proteins. They have a wide range of applications in food production and play a role as ingredients increasing nutritional value and simultaneously as functional additives forming physico-chemical, textural and rheological properties of products. (Misra 2008; Pescuma et al. 2008).

The least processed whey formulation is whey powder. Similarly to fresh whey, it can be divided into rennet and acid whey powder. Rennet whey powder, due to the lower content of peptides and free amino acids, which contribute to bitter taste, minerals, which, reveal in salty taste, and lactic acid causing sour flavour, has less impact on the taste of the final product. Moreover it has better solubility in comparison with acid whey. Therefore this formulation is wider used in food production than acid whey powder (Kosikowski 1979; Shon and Haque 2007). Rennet whey powder is used in dairy, bakery, confectionery and meat industry as well as in drinks formulations and infant food. Similarly to fluid form, powdered whey has number of applications as an additives incorporated into bread, pastries and other bakery products. It is also an ingredient of confectionery fillings, toppings and sugar coatings. In some extension powdered whey can replace milk powder in ice-creams, yoghurts and other dairy products (Misra 2008). Whey powder is also used in powdered food concentrates such as soups and sauces. Chavan et al. (2015a) developed tomato soup powder. They reported, that the samples of experimental soup fortified with whey powder had higher nutritional value and exhibited the rheological behaviour comparable to market products. The use of acid whey powder is limited, however, it also may be used in an bakery and pastry industry. According to Wronkowska et al. (2012), addition of acid whey powder to bread dough causes significant increase in the bread production yield. Moreover in bread prepared with acid whey powder, the color of crumbs was brighter and the crust browning was more intense.

Demineralised whey powder, obtained from whey concentrated in nanofiltration process, due to lower content of mineral components, has less salty taste thus lower impact on sensory properties of products. This formulation is commonly used in food production. In bakery it is used as an additive improving production yield of bread. Karolini-Skaradzińska et al. (2010) reported, that in case of wheat bread production, the optimal addition of demineralised whey powder to flour amounts $4 \%$. In dairy industry, this kind of whey powder is often used as less expensive substitution of skimmed milk powder. In the study of Glibowski and Krępacka (2006) it was stated, that 4\% addition of demineralised whey has positive impact on rheological properties of yoghurt in comparison with the samples without additives. Product with demineralised whey powder had the same range of viscosity like yogurt with skimmed milk powder though had lower hardness. Demineralised whey can be also utilized in ice-cream mixtures (Misra 2008).

The most extensively used whey formulations are whey protein concentrates (WPC) and whey protein isolates (WPI) which are obtained in the process of ultrafiltration and diafiltration of whey in order to concentrate whey proteins, and subsequently by drying the retentate usually in spray dryers. High nutritional quality of whey proteins is the reason, that WPC and WPI are commonly used in infant formulations, dietetic food and beverages and rich in proteins products for athletes and malnourished. The ability of whey protein to induce 
satiety is used in products for people wanting to lose weight (Childs et al. 2007; Gupta et al. 2012; Tavares et al. 2012). Moreover these formulation have the number of functional properties which are used in various branches of food industry. Whey proteins properties and examples of their applications are shown in Table 1.

Table 1. Functional properties and applications of whey proteins in food production (Alfaifi and Stathopoulous 2010, Gupta et al. 2012)

Tabela 1. Właściwości funkcjonalne oraz zastosowanie białek serwatkowych w produkcji żywności

\begin{tabular}{ll}
\hline \multicolumn{1}{c}{$\begin{array}{c}\text { Functional properties } \\
\text { Właściwości funkcjonalne }\end{array}$} & \multicolumn{1}{c}{\begin{tabular}{c}
\multicolumn{1}{c}{ Application } \\
Zastosowanie
\end{tabular}} \\
\hline solubility - rozpuszczalność & beverages - napoje \\
water absorption - absorpcja wody & $\begin{array}{l}\text { processed meat products, bakery products - prze- } \\
\text { twory mięsne, wyroby piekarnicze }\end{array}$ \\
viscosity - lepkość & soups, sauces - zupy, sosy \\
gelling - żelowanie & meat and fish products, desserts - przetwoty mięsne \\
& i rybne, desery \\
emulsifying properties - właściwości emulgujące & infant formulations - preparaty dla niemowląt \\
fat absorption - absorpcja tłuszczu & meat products - przetwory mięsne \\
foam forming properties - właściwości pianotwórcze & creams, desserts - kremy, desery \\
minerals binding - wiązanie minerałów & products enriched with minerals - żywność wzbo- \\
& gacona w minerały
\end{tabular}

In meat processing industry, due to gelling, emulsifying and water binding properties, whey proteins are used as additives in cold cuts, sausages and other products. In case of bakery industry, the addition of whey proteins increases the production yield, retards staling and improves sensory properties of bread and other baked products. WPC and WPI are an alternative to skimmed milk powder in productions of fillings, creams, puddings and other confectionery products, where gelling, emulsifying and foam forming properties are used. They are also used as thickening agents and fat replacement in manufacturing of low-calorie mayonnaise and sauces (Glibowski 2004; Grabiński and Przedpełski 2004; Brodziak et al. 2012).

Also dairy is a branch of food industry where whey proteins are often used. They constitute the ingredient of such products as ice-creams, yogurts and other fermented beverages or cheese analogues (Glibowski 2004). The researches performed by Sołowiej et al. (2008) revealed that WPC 35 and WPC 65 can be used as partial replacement of acid casein in production of processed cheeses. Obtained analogues of processed cheeses had better rheological properties than products with acid casein content. The utilization of whey proteins concentrates, especially WPC 35 which due to lower protein content is characterized with lower prices, allows to reduce the production cost. Nastaj et al. (2007) performed a study concerned the usage of WPI as a substitution of milk powder in dairy dessert production. In case of products sweetened with saccharose, the texture of the samples with WPI was similar to those made with milk powder addition. According to Hinrichs (2001), denaturated whey proteins may be incorporated into matrix of cheese. Heat denaturation causes that whey proteins are retained in the gel network and consequently production yield of cheese increase. The presence of whey protein contributes to the improvement of nutritional quality of cheese, however it may also results in a slightly poorer quality of cheese flavour and texture. Ismail et al. (2010) indicated, that heat denaturated buffalo whey proteins added to buffalo milk in amount of 0.5 or $1 \%$ significantly increased the yield of Mozzarella cheese 
production. Moreover the addition of whey protein improved the sensory properties of low-fat mozzarella cheese. Kokoszka and Lenart (2007) developed the food coatings with $6-10 \%$ of whey proteins content and with glycerol as a plasticizer. They concluded, that WPI may be used to produce edible coatings which can be use to protect food product and extend its shelf-life.

Microparticulated whey protein (MWP) is the formulation with wide possibilities of application in the dairy industry. The role of its addition is to improve production yield and nutritional properties of such products as cheeses and fermented beverages. Moreover microparticulated whey protein provides sensory sensations, such as creaminess and full mouthfeel, associated with the presence of milk fat. That is why this whey formulation is used as a fat replacement in low-fat yogurt production. It was showed, that MWP do not interact with casein micelles but they behave as homogenized fat globules in full-fat yogurt. Torres et al. (2011) obtained low-fat stirred yoghurt in which skimmed milk powder were replaced with MWP. Rheological and sensory properties of the samples were similar to those of full fat yogurts.

Whey permeates received during membrane concentration of whey may be also utilized in food industry. As it was previously mentioned, RO permeate constitutes potable water and may be used in food production. NF permeate is a rich source of minerals like potassium, sodium, calcium, magnesium, phosphorus, chloride, iron and zinc. In studies performed by Ceglińska et al. (2007) powder received by concentrating and drying of NF permeate was added to bread dough as a salt replacement. The results indicated, that it is possible to replace kitchen salt $(\mathrm{NaCl})$ with 2 to $3 \%$ of the whey-derived mineral component without deterioration of the wheat bread quality. The most valuable whey permeate is those obtained in UF process, which contains the considerable amounts of lactose - primary solid ingredient of whey and is extensively used as a source of this milk sugar. The development of lactose concentration, crystallization and purification techniques contributed to generation of many applications of whey-derived lactose, which is used not only in food production, but also has pharmaceutical and industrial applications. In food technology lactose is an additive in bakery and confectionary products as well as is an ingredient of infant formulations. and is used as an excipient in pharmaceuticals (Gänzle et al. 2008). Wide range of applications have derivatives of lactose hydrolysis, that is galactose and glucose. The mixtures of these monohydrates are used as sweetening syrups in bakery, confectionery and beverages production as a replacement of saccharose and glucose syrup (de Souza et al. 2010). Other lactose derivatives are: lactulose - a non-digestible carbohydrate with bifidogennic effects; lactitol - a non-caloric sweetener; lactobionic acid - a strong chelator of calcium, used in calcium supplements; galacto-oligosaccharides (GOS) - non-digestible carbohydrates with high bifidogenic activity which are promising prebiotic ingredients applicable to a variety of designed foods (Gänzle et al. 2008; Torres et al. 2010; Panesar and Kumari 2011).

\section{THE APPLICATION OF WHEY IN OTHER BRANCHES OF INDUSTRY}

Apart from food production, whey and whey-derived formulations are used in biotechnological and feed industry. Unprocessed fluid whey in some extend may be utilized as a forage for calves and piglets, though due to low dry matter and high lactose content, it cannot be given 
to animals in too big quantities. Whey powder is used as a feed ingredient in formulations for calves, pigs and poultry (Minakowski et al. 1998; Szczurek 2008). Moreover unprocessed whey and UF whey permeate have the high potential to be used in the biotechnology industry. This products are used as a raw material for the production of such compounds as lactic acid, acetic acid, ethyl alcohol, as well as the biogas (Panesar et al. 2007; Kosseva et al. 2009; Prazeres et al. 2012). Koutinas et al. (2009) reported, that whey constitutes a good medium for growth and fermentation of lactose converting microorganisms like lactic acid bacteria and yeasts, therefore it can be used for dairy starter cultures production. In spite of being good environment for growth of bacteria, fermented whey proved to be suitable cryoprotective agent, providing high viability of freeze-dried kefir cultures (Papavasiliou et al. 2008). These cryoprotective properties towards probiotic strains of Lactobacillus acidophilus and L. paracasei were described in study of Burns et al. (2008). Whey is also performed as a raw material for biomass and single cell protein (SCP) production which are used as protein source in animal feed (Gonzáles Siso 1996; Misra 2008).

Because of the valuable nutritional and functional properties and wide range of health benefits, whey and especially whey proteins possess a variety of applications in the pharmaceutical and cosmetic industries. The whey proteins are used as ingredients of pharmaceuticals and dietary supplements. In the cosmetics industry whey is used as a natural source of proteins, lactic acid, minerals and vitamins (Śliwa et al. 2011; Kalicka 2012). Thanks to foam forming and emulsion stabilizing properties, whey proteins are used as a component of a number of cosmetic formulas, such as shampoos, shower gels, bubble baths, creams and lotions. Lactoferrin is used as an antioxidant agent in skin care formulations and together with other whey protein lysozyme, is used as a bacteriostatic agent in toothpastes and antiseptic mouthwashes (Marshall 2004; Brodziak et al. 2012).

\section{CONCLUSIONS}

Large amount of global whey production and the zero waste technology trends caused the shift in the perception of whey which is not longer consider as a waste but has significant meaning in current industry. In the frame of extensive efforts to reduce the production costs and to find new ingredients with high nutritional value and good functional properties, the development of whey processing has a great impact on food production. The continuous increase in the whey production and better understanding of its nutritional and health-promoting properties contributes to the advances in technologies connected with whey utilization which include among others membrane filtration, concentration, isolation, purification and drying methods. A particularly important factor in favor of the development of new methods for the application of whey, is the high value of whey proteins, which are considered as the best possible protein source in human diet. The formulations with significant role in food productions are whey powder, demineralized whey powder, whey protein concentrates and isolates and modified whey proteins. Moreover wide range of applications has received from UF whey permeate lactose and its derivatives. Beside food production, whey is commonly used in other branches like feed, biotechnological, pharmaceutical and cosmetics industries. 


\section{REFERENCES}

Alfaifi M. S., Stathopoulos C.E. 2010. Effect of egg yolk substitution by sweet whey protein isolate on texture, stability and colour of Gelato-style vanilla ice cream. Int. J. Dairy Technol. 63, 593-598. DOI: 10.1111/j.1471-0307.2010.00609.x.

Bednarski W. 2001. Doskonalenie technologii oraz organizacji przetwarzania serwatki w Polsce [Improving the technology and organization of whey processing in Poland]. Przem. Spoż. 2, 32-34, 44. [in Polish]

Brodziak A., Król J., Litwińczuk Z. 2012. Białka serwatkowe - właściwości funkcjonalne i zastosowanie [The whey protein functional properties and applications]. Przem. Spoż. 3(66), 35-37. [in Polish]

Burns P., Vinderola G., Molinari F., Reinheimer J. 2008. Suitability of whey and buttermilk for the growth and frozen storage of probiotic lactobacilli. Int. J. Dairy Technol. 61, 156-164. DOI: 10.1111/j.1471-0307.2008.00393.x.

Ceglińska A., Pluta A., Skrzypek J., Krawczyk P. 2007. Badania nad zastosowaniem do produkcji pieczywa składników mineralnych otrzymanych po nanofiltracji serwatki [Studies on the use for the production of bread minerals obtained from nanofiltration of whey]. Żyw. Nauka Technol. Jakość 6(55), 234-241. [in Polish]

Chavan R., Kumar A., Basu S., Nema P.K., Nalawade T. 2015a. Whey based tomato soup powder: rheological and color properties. IJASR. 4(5), 301-313.

Chavan R.S., Shraddha R.C., Kumar A., Nalawade T. 2015b. Whey based beverage: Its functionality, formulations, health benefits and applications. J. Food Proc. Technol. 6(10), 1-8. DOI:10.4172/2157$-7110.1000495$.

Childs J.L., Yates M.D., Drake M.A. 2007. Sensory properties of meal replacement bars and beverages made from whey and soy proteins. J.F.S. 72, S425-S434. DOI: 10.1111/j.1750-3841.2007.00429.x.

Chojnowski W., Dec B. 2008. Procesy membranowe w mleczarstwie, w: Mleczarstwo. T. 1. Red. S. Ziajka. Olsztyn, Wydaw. UWM, 337-388. [in Polish]

Clare D.A., Daubert C.R. 2010. Transglutaminase catalysis of modified whey protein dispersions. J.F.S. 75, C369-C377. DOI: 10.1111/j.1750-3841.2010.01605.x.

Dajnowiec F., Zander Z. 2013. Współczesne techniki przetwarzania serwatki - przegląd literaturowy [Modern techniques of processing whey - literature review]. Prz. Mlecz. 1, 35-37. [in Polish]

Darade R.V., Ghodake S.S. 2012. An overview of whey beverages. Res. J. Animal. Hus. Dairy Sci. 3(1), 41-44.

Foegeding A.E., Davis J.P., Doucet D., McGuffey M.K. 2002. Advances in modifying and understanding whey protein functionality. Trends Food Sci. Tech. 13, 151-159. DOI: 10.1016/S0924-2244(02)00111-5.

Fuente M.A. de la, Hemar Y., Tamehana M., Munro P.A., Singh H. 2002. Process-induced changes in whey proteins during the manufacture of whey protein concentrates. Int. Dairy J. 12, 361-369. DOI: 10.1016/S0958-6946(02)00031-6.

Gänzle M.G., Haase G., Jelen P. 2008. Lactose: Crystallization, hydrolysis and value-added derivatives. Int. Dairy J. 18, 685-694. DOI: 10.1016/j.idairyj.2008.03.003.

Glibowski P. 2004. Zastosowanie białek serwatkowych w przemyśle spożywczym [The use of whey protein in the food industry]. Prz. Mlecz. 9, 10-13. [in Polish]

Glibowski P., Krępacka A. 2006. Wpływ dodatku preparatów serwatki na właściwości reologiczne jogurtów [Effect of addition of whey preparations on rheological properties of yoghurt]. Żyw. Nauka Technol. Jakość 1(46), 75-82. [in Polish]

Gonzáles Siso M.I. 1996. The biotechnological utilization of cheese whey: a review. Biores. Technol. 57, 1-11. DOI: 10.1016/0960-8524(96)00036-3.

Grabiński K., Przedpełski M. 2004. Białka serwatkowe - zdrowie i funkcjonalność [Whey protein health and functionality]. Przem. Spoż. 5, 32-33. [in Polish] 
Gupta C., Prakash D., Garg A.P., Gupta S. 2012. Whey proteins: A novel source of bioceuticals. Middle East J. Sci. Res. 12(3), 365-375.

Hinrichs J. 2001. Incorporation of whey proteins in cheese. Int. Dairy J. 11, 495-503. DOI: 10.1016/ IS0958-6946(01)00071-1.

Ismail M., Ammar E., El-Metwally R. 2010. Improvement of low fat mozzarella cheese properties using denatured whey protein. Int. J. Dairy Technol. 64, 207-217. DOI: 10.1111/j.1471-0307.2010.00654.x.

Jeličić I., Božanić R., Tratnik L. 2008. Whey-based beverages - a new generation of dairy products. Mljekarstvo 58(3), 257-274.

Kakan A., Changade S., Chopde S. 2015. Effect of incorporation of Paneer whey on dough characteristics and organoleptic attributes of milk bread. Asian J. Dairy Food Res. 1002, 1-6. DOI: 10.18805/ajdfr.v0iof.9615.

Kalicka D. 2012. Niedoceniony lek: serwatka [Underestimated medicine: whey]. Por. Zdrow. 20, 17-20. [in Polish]

Karolini-Skaradzińska Z., Czubaszek A., Kuczak D., Frączak A. 2010. Jakość ciasta i pieczywa pszennego $z$ dodatkiem serwatki [Quality of wheat dough and bread containing whey additive]. Żyw. Nauka Technol. Jakość 6(73), 46-57. [in Polish]

Kłobukowski J., Kozikowski W. 2008. Wartość żywieniowa mleka, w: Mleczarstwo. T. 1. Red. S. Ziajka. Olsztyn, Wydaw. UWM, 101-118. [in Polish]

Kokoszka S., Lenart A. 2007. Wybrane właściwości fizyczne powłok jadalnych serwatkowych [Selected physical properties of whey protein based edible coatings]. Żyw. Nauka Technol. Jakość 5(54), 321-328. [in Polish]

Kosikowski F. V. 1979. Whey utilization and whey products. J. Dairy Sci. 7(62), 1149-1160.

Kosseva M.R., Panesar P.S., Kaurb G., Kennedy J.F. 2009. Use of immobilised biocatalysts in the processing of cheese whey. Int. J. Biol. Macromol. 45, 437-447. DOI: 10.1016/j.jjbiomac.2009.09.005.

Koutinas A.A., Papapostolou H., Dimitrellou D., Kopsahelis N., Katechaki E., Bekatorou A., Bosnea L.A. 2009. Whey valorisation: A complete and novel technology development for dairy industry starter culture production. Biores. Technol. 100, 3734-3739. DOI: 10.1016/j.biortech.2009.01.058.

Kroll J., Budzyński J. 2001. Zastosowanie procesów membranowych w przetwórstwie serwatki [The use of membrane techniques in the processing of whey]. Prz. Mlecz. 2, 66-68. [in Polish]

Leman J. 2006. Enzymatyczna modyfikacja białek serwatkowych [Enzymatic modification of whey proteins]. Przem. Spoż. 12, 26-29,41. [in Polish]

Leman J., Dolgan T. 2001. Frakcjonowanie białek serwatkowych [Fractionation of whey proteins]. Przem. Spoż. 12(55), 41-45. [in Polish]

Mahmoud N.S., Ghaly A.E. 2004. On-line sterilization of cheese whey using ultraviolet radiation. Biotechnol. Progr. 20, 550-560. DOI: 10.1021/bp030050i.

Marriott N.G., Wang H., Claus J.R., Graham P.P. 1998. A research note evaluation of restructured lowOfat ham containing whey. J. Muscle Foods 9, 201-207. DOI: 10.1111/j.1745-4573.1998.tb00655.x.

Marshall K. 2004. Therapeutic applications of whey proteins. Alter. Med. Rev. 9, 136-156.

McIntosh G.H., Royle P.J., Le Leu R.K., Regester G.O., Johnson M.A., Grinsted R.L., Kenward R.S., Smithers G.W. 1998. Whey proteins as functional food ingredients? Int. Dairy J. 8, 425-434. DOI:10.1016/S0958-6946(98)00065-X.

Minakowski D., Lipiński K., Tywończuk J. 1998. Suszona serwatka w żywieniu zwierząt [Dried whey in Animals feed]. Prz. Mlecz. 4, 119-121. [in Polish]

Misra A. K. 2008. Whey management in dairying. Dairy Year Book 2008, 125-128.

Nastaj M., Gustaw W. Sołowiej B. 2007. Właściwości reologiczne deserów otrzymanych z białek serwatkowych $z$ dodatkiem różnych substancji słodzących [The rheological properties of milk desserts obtained from the whey proteins with the addition of different sweeteners]. Żyw. Nauka Technol. Jakość 5(54), 283-291. [in Polish]

Panesar P.S., Kennedy J.F., Gandhi D.N., Bunko K. 2007. Bioutilisation of whey for lactic acid production. Food Chem. 105, 1-14. DOI: 10.1016/j.foodchem.2007.03.035.

Panesar P.S., Kumari S. 2011. Lactulose: Production, purification and potential applications. Biotechnol. Adv. 29, 940-948. DOI: 10.1016/j.biotechadv.2011.08.008. 
Papavasiliou G., Kourkoutas Y., Rapti A., Sipsas V., Soupioni M., Koutinas A.A. 2008. Production of freeze-dried kefir culture using whey. Int. Dairy J. 18, 247-254. DOI: 10.1016/j.idairyj.2007.09.005.

Pereira C., Henriques M., Gomes D., Gomez-Zavaglia A., Antoni G. de. 2015. Novel Functional Whey-Based Drinks with Great Potential in the Dairy Industry. Food Technol. Biotech. 53(3), 307-314. DOI: 10.17113/ft b.53.03.15.4043.

Pescuma M. Hébert E.M., Mozzi F., Font de Valdez G. 2008. Whey fermentation by thermophilic lactic acid bacteria: Evolution of carbohydrates and protein content. Food Microbiol. 25, 442-451. DOI: 10.1016/j.fm.2008.01.007.

Pescuma M., Hébert E.M., Mozzi F., Font de Valdez G. 2010. Functional fermented whey-based beverage using lactic acid bacteria. Int. J. Food Microbiol. 141, 73-81. DOI: 10.1016/j.jfoodmicro.2010.04.011.

Philippopoulos C.D., Papadakis M.T. 2001. Current trends in whey processing and utilization in Greece. Int. J. Dairy Technol. 1(54), 14-19. DOI: 10.1046/j.1471-0307.2001.00007.x.

Prazeres A.R., Carvalho F., Rivas J. 2012. Cheese whey management: A review. J. Environ. Manag. 110, 48-68. DOI: 10.1016/j.jenvman.2012.05.018.

Roest K. de, Menghi A. 2000. Reconsidering 'traditional' food: The case of Parmigiano Reggiano cheese. Soc. Rur. 4(40), 439-451.

Shon J., Haque Z.U. 2007. Functional attributes of native and thermized sour and sweet whey. Int. J. Dairy Technol. 60, 135-142. DOI: 10.1111/j.1471-0307.2007.00316.x.

Smithers G.W. 2008. Whey and whey proteins - From 'gutter-to-gold'. Int. Dairy J. 18, 155-165. DOI: 10.1016/j.idairyj.2008.03.008.

Sołowiej B., Gustaw W., Nastaj M. 2008. Wpływ dodatku koncentratów białek serwatkowych na właściwości reologiczne analogów serów topionych [Effect of the addition of whey protein concentrates on rheological properties of processed cheese analogs]. Żyw. Nauka. Technol. Jakość 5(60), 226-234. [in Polish]

Souza R.R. de, Bergamascoa R., Costab S.C. da, Fengc X., Dariaa S.H.B., Gimenesa M.L. 2010. Recovery and purification of lactose from whey. Chem. Eng. Process. 49, 1137-1143. DOI: 10.1016/ /j.cep.2010.08.015.

Szczurek W. 2008. Produkty przetwarzania serwatki i ich zastosowanie w paszy dla kurcząt brojlerów aspekt żywieniowy i fizjologiczny [Whey processing products and their use in broiler chickens feed - nutritional and physiological aspects]. Wiad. Zootech. 4(96), 41-52. [in Polish]

Szymański E., Szpendowski J., Żywica R., Banach J.K. 2010. Wpływ dodatku koncentratu partukułowanych białek serwatkowych do mleka na jego właściwości elektryczne [Effect of particulated whey protein concentrate (pwpc) added to cheese milk on its electrical proprieties]. Żywn. Nauka Technol. Jakość 1(68), 58-70. [in Polish]

Śliwa K., Sikora E., Ogonowski J. 2011. Zastosowanie serwatki w produkcji szamponów [The use of whey in shampoos production]. Czasop. Techn. Chemia 108, 205-211. [in Polish]

Tavares T.G., Amorim M., Gomes D., Pintado M.E., Pereira C.D., Palcata F.X. 2012. Manufacture of bioactive peptide-rich concentrates from Whey: Characterization of pilot process. J. Food Eng. 110, 547-552. DOI: 10.1016/j.jfoodeng.2012.01.009.

Torres D.P.M., Goncalves M.P.F., Teixeira J.A., Rodrigues L.R. 2010. Galacto-oligosaccharides: Production, properties, applications, and significance as prebiotics. Compr. Rev. Food Sci. Food Saf. 9, 438-454. DOI: 10.1111/j.1541-4337.2010.00119.x.

Torres I.C., Janhøj T., Mikkelsen B.Ø., Ipsen R. 2011. Effect of microparticulated whey protein with varying content of denatured protein on the rheological and sensory characteristics of low-fat yoghurt. Int. Dairy J. 21, 645-655. DOI: 10.1016/j.idairyj.2010.12.013.

Wronkowska M., Soral-Śmietana M., Zander L., Zander Z., Jadacka M. 2012. Kształtowanie cech technologicznych i jakości chleba poprzez udział przemysłowego koncentratu serwatki potwarogowej [The moulding of technological properties and quality of bread by adding industrially produced concentrate of acid-whey obtained during the making of cottage cheese]. Żyw. Nauka Technol. Jakość 2(81), 56-67. [in Polish] 
Yetim H., Müller W.D., Eber M. 2001. Using fluid whey in comminuted meat products: effects on technological, chemical and sensory properties of frankfurter-type sausages. Food Res. Int. 34, 97-101. DOI: 10.1111/j.1745-4573.2006.00055.x.

Yetim H., Müller W.D., Dogan M., Klettner P.G. 2006. Using fluid whey in comminuted meat products: effects on textural properties of frankfurter-type sausages. J. Muscle Foods. 17, 354-366. DOI: 10.1111/j.1745-4573.2006.00055.x

Zander L., Zander Z. 2007. Współczesne techniki przetwarzania serwatki [Modern techniques of whey processing]. Prz. Mlecz. 12, 38-41. [in Polish]

Żelazna K., Popielarska A. 2003. Mleko i produkty mleczarskie w żywieniu człowieka [Milk and dairy products in human nutrition]. Przem. Spoż. 10, 26-31. [in Polish]

Abstract. Whey is a by-product of dairy industry obtained during cheese and casein production. Despite the low dry matter content, whey is a valuable by-product in terms of functional and nutritional properties and it has high potential of application. In the past it was treated as a problematic waste, but nowadays due to increasing amount of whey production and better knowledge about its properties, the whey processing technology is dynamically developing. The aim of the review was a presentation of methods used in whey application and characterization of formulations obtained from whey. Furthermore the article presents the current trends of whey utilizing mainly in the production of food and also in other branches of industry. 